\title{
In vitro morphogenesis of Physalis ixocarpa Brot ex. Horm. ${ }^{1}$
}

\author{
Domitzel Zagal Alvarado², Andressa Priscila Piancó Santos Lima², \\ José Raniere Ferreira de Santana ${ }^{2}$, Alone Lima-Brito ${ }^{2}$
}

\section{ABSTRACT}

Physalis ixocarpa Brot. ex Horm. is considered the most economically important species of the genus. Tissue culture is pointed out as a strategy for its propagation, but researches indicate that in vitro responses are genotype-dependent. This study aimed to evaluate the in vitro morphogenesis of the $P$. ixocarpa green and purple varieties, in view of the massive propagation of the species. The morphogenic capacity of the explants cotyledonary node, hypocotyl and cotyledon was evaluated in Murashige \& Skoog medium supplemented with benzylaminopurine - BAP $(0.00,2.5,5.0,7.5$ or $10.0 \mu \mathrm{M})$ and naphthaleneacetic acid - NAA $(0.00$ or $2.5 \mu \mathrm{M})$, using a completely randomized experimental design, in a $3 \times 5 \times 2$ factorial scheme, with 30 treatments for each variety. The number of shoots per direct and indirect organogenesis and the percentage of explants with callus were analyzed. The in vitro morphogenetic expression of $P$. ixocarpa is influenced by the type of explant and by the plant regulators BAP and NAA. The cotyledonary node explant is efficient for the production of shoots via direct organogenesis in the two varieties studied.

KEYWORDS: Solanaceae, husk tomato, plant propagation, tissue culture.

\section{INTRODUCTION}

Species of the Physalis genus have stood out in the group of small fruits due to their nutritional and economic value (Nunes et al. 2018). Considered the most commercially important species of this genus (Hernández et al. 2012), Physalis ixocarpa Brot. ex Horm., popularly known as tomatillo, has great economic importance in Mexico, due to its applicability in traditional cuisine and medicine (Ramos-Lopez et al. 2018), which are the reasons for its exploitation potential in other countries, including Brazil, where it has been introduced in the cultivation of exotic fruits with a high added value (Barroso et

\section{RESUMO}

Morfogênese in vitro de Physalis ixocarpa Brot ex. Horm.

Physalis ixocarpa Brot. ex Horm. é considerada a espécie economicamente mais importante do gênero. A cultura de tecidos é apontada como uma estratégia para a sua propagação; no entanto, pesquisas indicam que as respostas in vitro são genótipo-dependentes. Objetivou-se avaliar a morfogênese in vitro das variedades verde e roxa de $P$. ixocarpa, tendo-se em vista a propagação massiva da espécie. A capacidade morfogênica dos explantes nó cotiledonar, hipocótilo e cotilédone foi avaliada em meio Murashige \& Skoog suplementado com benzilaminopurina - $\operatorname{BAP}(0,00 ; 2,5 ; 5,0 ; 7,5$; ou $10,0 \mu \mathrm{M})$ e ácido naftalenoacético - ANA $(0,00$ ou $2,5 \mu \mathrm{M})$, utilizando-se delineamento experimental inteiramente casualizado, em esquema fatorial $3 \times 5 \times 2$, sendo 30 tratamentos para cada variedade. Foram analisados o número de brotos por organogênese direta e indireta e a porcentagem de explantes com calo. A expressão morfogenética in vitro de P. ixocarpa é influenciada pelo tipo de explante e pelos reguladores vegetais BAP e ANA. O explante nó cotiledonar é eficiente para a produção de brotos via organogênese direta nas duas variedades estudadas.

PALAVRAS-CHAVE: Solanaceae, tomate de cáscara, propagação de plantas, cultura de tecidos.

al. 2017). This Solanaceae species has a small and globose fruit, with soft texture and green, yellow or purple color (Rufato 2013), according to the variety.

The conventional method for P. ixocarpa propagation is through seeds, but the great genetic variability obtained by sexual propagation does not guarantee a constant production of seedlings (GarcíaOsuna et al. 2015) with quality standard to meet the market requirements. The maintenance of the uniformity of plant material can be obtained by vegetative reproduction methods such as micropropagation, which consists of the large-scale propagation of plants, with genetic and phytosanitary quality, in a brief period of time and reduced space (Pasqual et al. 2008).

\footnotetext{
${ }^{1}$ Received: June 23, 2021. Accepted: Sep. 13, 2021. Published: Nov. 08, 2021. DOI: 10.1590/1983-40632021v5169416.

${ }^{2}$ Universidade Estadual de Feira de Santana, Departamento de Ciências Biológicas, Feira de Santana, BA, Brasil.

Email/ORCID: domitzela@gmail.com/0000-0001-8295-1800; andressapianco@gmail.com/0000-0002-8272-3506; jose.raniere@gmail.com/0000-0003-0186-6888; alone@uefs.br/0000-0003-3481-6481.
} 
From the in vitro inoculation of the explants, propagation may occur by direct organogenesis or embryogenesis, in which somatic organs or embryos arise directly from the explant tissue, or by indirect organogenesis or embryogenesis, in which cellular dedifferentiation is accompanied by growth of the callus, which, under appropriate conditions, is capable of generating somatic organs or embryos (Levitus et al. 2010).

For the establishment of a micropropagation protocol, it is necessary to evaluate the influence of several factors on the morphogenesis control, especially the species, culture medium, environmental conditions, type of explant, given its morphogenic capacity, and plant regulators, which act as stimulators of in vitro regeneration (Peres 2002, Morais et al. 2014, Goelzer et al. 2019). Auxins and cytokinins are widely used in the induction of in vitro morphogenesis, as they act in the regulation of cell division and differentiation (Kerbauy 2019).

In vitro studies with $P$. ixocarpa began in the 1980s with the culture of protoplasts (Bapat \& Schieder 1981) and obtaining of haploid embryos and plants through the cultivation of microspores (Bapat \& Wenzel 1982), with subsequent exploration of anther culture, somatic embryogenesis and direct and indirect organogenesis in the improvement of the in vitro morphogenic capacity of the species (Manzo-González et al. 1998, Contreras \& Puentes 2003, Andrade-Rodríguez et al. 2005, EscobarGuzmán et al. 2009, García-Osuna et al. 2015). According to Andrade-Rodríguez et al. (2005), the diversity of responses in the formation of shoots among $P$. ixocarpa genotypes results from the influence of genetic diversity on the totipotency of cells. The authors suggest the establishment of specific protocols for the propagation of this species.

In order to elucidate the best path for commercial-scale propagation, this study aimed to evaluate the influence of different explants and concentrations of the plant regulators benzylaminopurine (BAP) and naphthaleneacetic acid (NAA) on the in vitro morphogenesis of the Physalis ixocarpa green and purple varieties.

\section{MATERIAL AND METHODS}

The experiment was conducted at the Universidade Estadual de Feira de Santana, in Feira de Santana (Bahia state, Brazil), from August 2018 to March 2019.

Physalis ixocarpa plants of the purple and green varieties were established in vitro in MS medium (Murashige \& Skoog 1962) with half the salt concentrations (MS 1/2), supplemented with $30 \mathrm{~g} \mathrm{~L}^{-1}$ of sucrose, gelled with $7 \mathrm{~g} \mathrm{~L}^{-1}$ of agar (basic medium). Seed disinfestation followed the protocol by Mascarenhas et al. (2019).

Plants of 12-13 days of age, grown from in vitro germination, were used as a source of explants for induction of in vitro morphogenesis. Three types of explant (cotyledon, hypocotyl and cotyledonary node) with $1 \mathrm{~cm}$ were individually inoculated in test tubes with $15 \mathrm{~mL}$ of the basic medium plus 0.0 , $2.5,5.0,7.5$ or $10.0 \mu \mathrm{M}$ of BAP and 0.0 or $2.5 \mu \mathrm{M}$ of NAA. The experimental design was completely randomized, in a $3 \times 5 \times 2$ factorial scheme (three types of explants $\mathrm{x}$ five BAP concentrations $\mathrm{x}$ two NAA concentrations), totaling 30 treatments for each variety, which were composed of five replicates with four samples each. After 30 days, the means for number of shoots obtained by direct and indirect organogenesis and the percentage of explants with calluses were analyzed. The $\mathrm{pH}$ of the medium was adjusted to 5.7 before autoclaving, performed at $121^{\circ} \mathrm{C}$, for $15 \mathrm{~min}$

The experiment was conducted in a growth room with temperature of $25 \pm 3{ }^{\circ} \mathrm{C}$, under white fluorescent light $\left(60 \mu \mathrm{mol} \mathrm{m} \mathrm{m}^{-2} \mathrm{~s}^{-1}\right)$ and photoperiod of 16 hours. The obtained data were subjected to analysis of variance (Anova) using the Sisvar statistical software (Ferreira 2019), followed by comparison of means by the Tukey test at $5 \%$ of probability for qualitative data and regression analysis for quantitative data.

\section{RESULTS AND DISCUSSION}

According to the analysis of variance, for the Physalis ixocarpa green variety, the double interactions between the type of explant and BAP, type of explant and NAA, and between BAP and NAA were significant for the number of shoots per explant. Regarding the interaction between the type of explant and BAP concentrations, it was observed that the best results were obtained with the cotyledon explant under the intermediate concentrations used, 2.5 and $5.0 \mu \mathrm{M}$ of BAP, with means of 2.35 and 2.30 shoots per explant, respectively (Table 1 ). This 
same explant was superior in the interaction between type of explant and NAA, in which the best results were obtained in the absence of this auxin (Figure 1; Table 1).

The obtained data regarding number of shoots in the BAP $x$ NAA interaction were described by a quadratic polynomial model for BAP concentrations, with maximum points of 3.85 and 4.59 at NAA concentrations of 0 and $2.5 \mu \mathrm{M}$, respectively. The estimated values for the number of shoots were 1.52 for $0 \mu \mathrm{M}$ of NAA and 0.51 for $2.5 \mu \mathrm{M}$ of this auxin (Figure 2).

According to the analysis of variance, for the P. ixocarpa purple variety, the factors type of explant, BAP and NAA concentrations had a significant triple interaction $(p \leq 0.05)$ for the number of shoots per explant. This interaction is demonstrated by the
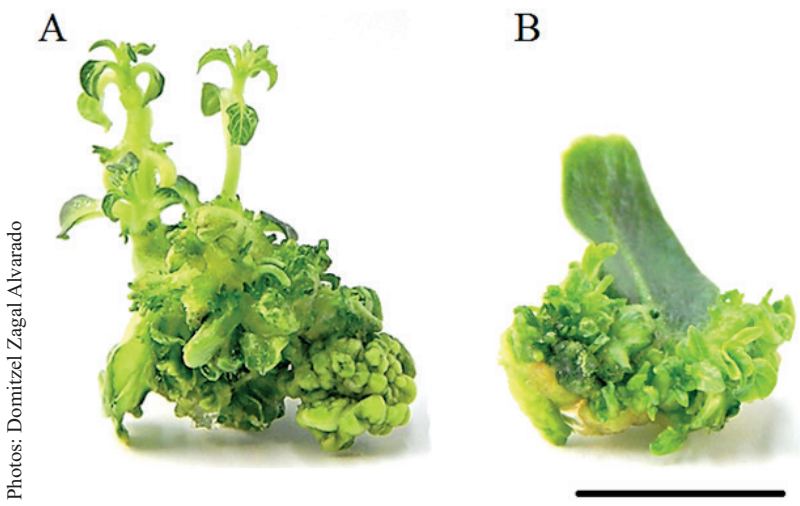

Figure 1. Morphogenic response of the Physalis ixocarpa green variety in two types of explant cultured in vitro for 30 days. A) cotyledonary node; B) cotyledon. Bar: $1 \mathrm{~cm}$.

Table 1. Number of shoots formed by direct organogenesis in three types of explant of the Physalis ixocarpa green variety under isolated effects of benzylaminopurine (BAP) and naphthaleneacetic acid (NAA) concentrations.

\begin{tabular}{cccc}
\hline \multirow{2}{*}{ BAP $(\mu \mathrm{M})$} & \multicolumn{3}{c}{ Type of explant } \\
\cline { 2 - 4 } & Cotyledon & Hypocotyl & Cotyledonary node \\
\hline 0.0 & $0.00 \mathrm{Bb}^{*}$ & $0.25 \mathrm{Ba}$ & $1.25 \mathrm{Ab}$ \\
2.5 & $1.25 \mathrm{Ba}$ & $0.12 \mathrm{Ca}$ & $2.35 \mathrm{Aa}$ \\
5.0 & $0.52 \mathrm{Bab}$ & $0.25 \mathrm{Ba}$ & $2.30 \mathrm{Aa}$ \\
7.5 & $0.02 \mathrm{Bb}$ & $0.00 \mathrm{Ba}$ & $1.05 \mathrm{Ab}$ \\
10.0 & $0.00 \mathrm{Ab}$ & $0.00 \mathrm{Aa}$ & $0.62 \mathrm{Ab}$ \\
\hline NAA $(\mu \mathrm{M})$ & Cotyledon & Hypocotyl & Cotyledonary node \\
\hline 0.0 & $0.71 \mathrm{Ba}$ & $0.12 \mathrm{Ca}$ & $2.07 \mathrm{Aa}$ \\
2.5 & $0.01 \mathrm{Bb}$ & $0.04 \mathrm{Ba}$ & $0.96 \mathrm{Ab}$ \\
\hline
\end{tabular}

* Distinct letters indicate different means according to the Tukey test $(\mathrm{p} \leq 0.05)$. Uppercase letters compare explants and lowercase letters compare BAP or NAA concentrations.

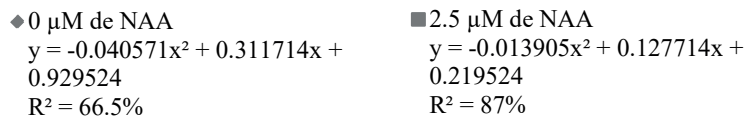

$2.5 \mu \mathrm{M}$ de NAA

$\mathrm{y}=-0.013905 \mathrm{x}^{2}+0.127714 \mathrm{x}+$ 0.219524

$\mathrm{R}^{2}=87 \%$

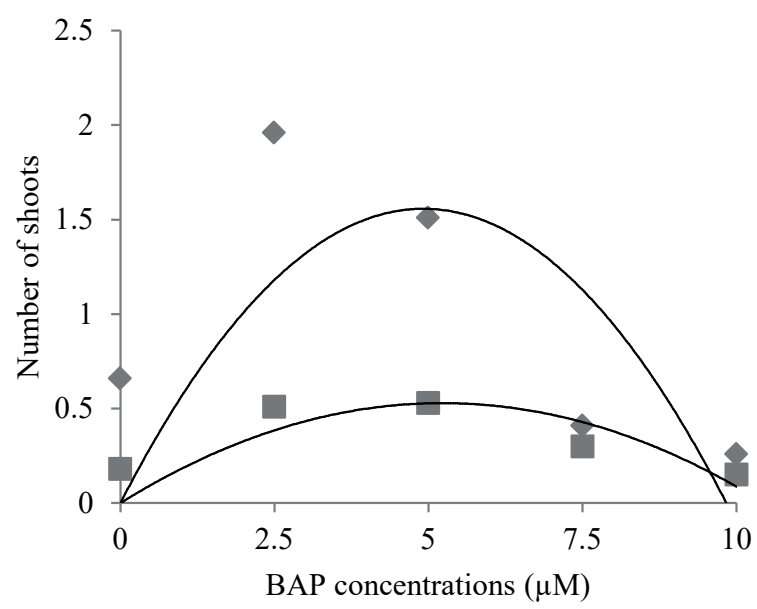

Figure 2. Number of shoots per explant of the Physalis ixocarpa green variety obtained by direct organogenesis under the effect of the interaction between benzylaminopurine (BAP) and naphthaleneacetic acid (NAA) concentrations.

mean of 0.70 in the association of $2.5 \mu \mathrm{M}$ of BAP, absence of NAA and the explant cotyledonary node. However, a similar mean of 0.75 was obtained for the same explant in the absence of BAP combined or not with NAA (Table 2), which promotes a reduction of production costs for the medium without plant regulator. The other evaluated treatments did not show a response, or means of 0.05 shoots per explant were recorded (Figure 3; Table 3).

Research studies indicate that there is an important discrepancy as to the best explant for the induction of shoots in P. ixocarpa (Contreras \& Puentes 2003, García-Osuna et al. 2015). However, the results of this study show that, for both the $P$. ixocarpa purple and green varieties, the highest means for the formation of these structures were achieved with the cotyledon explant. The 2.35 shoots per explant for the green variety subjected to 2.5 and $5.0 \mu \mathrm{M}$ of BAP and 0.75 shoots for the purple variety in medium with no plant regulator demonstrate that the endogenous hormonal concentration varies among the varieties studied, what confirms the importance of establishing specific protocols for in vitro propagation.

The highest means reported in the literature for the in vitro propagation of $P$. ixocarpa were 
Table 2. Number of shoots per explant via direct organogenesis in three explants of the Physalis ixocarpa purple variety under different benzylaminopurine (BAP) and naphthaleneacetic acid (NAA) concentrations.

\begin{tabular}{clccccc}
\hline \multirow{2}{*}{ NAA $(\mu \mathrm{M})$} & \multirow{2}{*}{ Explant } & \multicolumn{5}{c}{$\mathrm{BAP}(\mu \mathrm{M})$} \\
\cline { 3 - 6 } & Cotyledonary node & $0.75 \mathrm{Aa}$ & $0.70 * \mathrm{Aa}$ & $0.05 \mathrm{Ab}$ & $0.05 \mathrm{Ab}$ & $0.00 \mathrm{Ab}$ \\
\multirow{2}{*}{0.0} & Cotyledon & $0.00 \mathrm{Ba}$ & $0.00 \mathrm{Ba}$ & $0.00 \mathrm{Aa}$ & $0.00 \mathrm{Aa}$ & $0.00 \mathrm{Aa}$ \\
& Hypocotyl & $0.05 \mathrm{Ba}$ & $0.00 \mathrm{Ba}$ & $0.00 \mathrm{Aa}$ & $0.00 \mathrm{Aa}$ & $0.00 \mathrm{Aa}$ \\
\hline \multirow{2}{*}{2.5} & Cotyledonary node & $0.75 \mathrm{Aa}$ & $0.00 \mathrm{Ab}$ & $0.00 \mathrm{Ab}$ & $0.00 \mathrm{Ab}$ & $0.00 \mathrm{Ab}$ \\
& Cotyledon & $0.00 \mathrm{Ba}$ & $0.05 \mathrm{Aa}$ & $0.00 \mathrm{Aa}$ & $0.00 \mathrm{Aa}$ & $0.00 \mathrm{Aa}$ \\
& Hypocotyl & $0.00 \mathrm{Ba}$ & $0.00 \mathrm{Aa}$ & $0.00 \mathrm{Aa}$ & $0.00 \mathrm{Aa}$ & $0.00 \mathrm{Aa}$ \\
\hline
\end{tabular}

* Indicates a statistically higher mean between the NAA concentrations. Distinct letters indicate different means according to the Tukey test ( $\mathrm{p} \leq 0.05$ ). Uppercase letters compare explants and lowercase letters compare BAP concentrations.

Table 3. Percentage of callogenesis in explants of the Physalis ixocarpa green variety under different benzylaminopurine (BAP) and naphthaleneacetic acid (NAA) concentrations.

\begin{tabular}{cccccc}
\hline \multirow{2}{*}{ NAA $(\mu \mathrm{M})$} & \multicolumn{5}{c}{$\mathrm{BAP}(\mu \mathrm{M})$} \\
\cline { 2 - 5 } & 0 & 2.5 & 5 & 7.5 & 10 \\
\hline 0.0 & $16.60 \mathrm{Bab}^{*}$ & $40.00 \mathrm{Ba}$ & $11.66 \mathrm{Bab}$ & $18.33 \mathrm{Bab}$ & $0.00 \mathrm{Bb}$ \\
2.5 & $41.55 \mathrm{Ab}$ & $73.33 \mathrm{Aa}$ & $80.00 \mathrm{Aa}$ & $70.00 \mathrm{Aab}$ & $53.33 \mathrm{Aab}$ \\
\hline
\end{tabular}

* Distinct letters indicate different means according to the Tukey test $(\mathrm{p} \leq 0.05)$. Uppercase letters compare NAA concentrations and lowercase letters compare BAP concentrations.

A

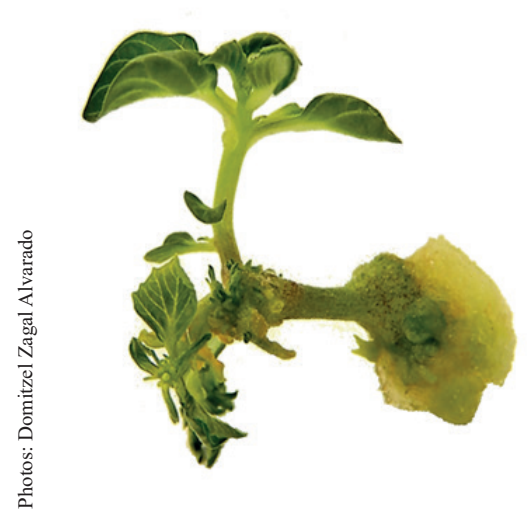

B

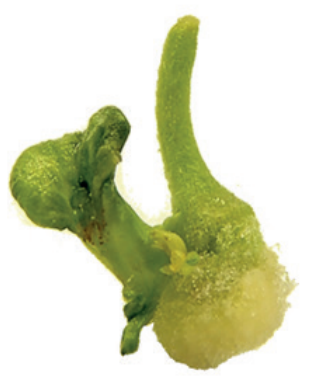

$\mathrm{C}$

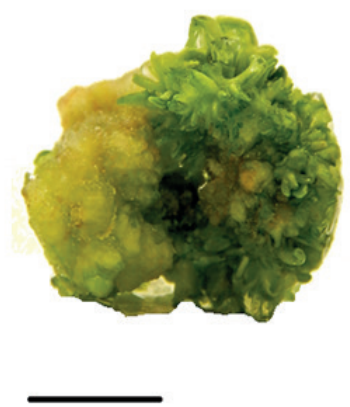

Figure 3. Variability in the morphogenic response of the Physalis ixocarpa purple variety in three types of explant cultured in vitro for 30 days. Evaluation performed 30 days after inoculation. A) cotyledonary node; B) hypocotyl; C) cotyledon. Bar: $1 \mathrm{~cm}$.

obtained from the hypocotyl explant by Contreras \& Puentes (2003) and Andrade-Rodríguez et al. (2005), respectively. These results differ from those reported by García-Osuna et al. (2015) and observed in the present study, in which the use of the explant hypocotyl resulted in lower levels, or in the absence of morphogenesis. It is important to note that Andrade-Rodríguez et al. (2005) considered as shoots structures with length of $1-5.7 \mathrm{~cm}$, structures that these authors classified as small and unable to grow and be used for micropropagation, while
Contreras \& Puentes (2003) do not detail the length of the structures they considered as shoots. Therefore, the means presented in this study, regarding the number of shoots, are not comparable with those reported by these researchers, since, for both varieties studied, there was the formation of undefined shoot structures, of hard and non-individualized consistency, with length of less than $0.5 \mathrm{~cm}$; and although some of them had small leaves, they did not have stems, so they were not classified as shoots (Figure 4). These structures, when subjected to 




Figure 4. Formation of undefined structures of Physalis ixocarpa cultured in vitro for 30 days. A) purple variety; B) green variety. Bar: $1 \mathrm{~cm}$.

different BAP concentrations and in a regulator-free medium, showed no development, unlike the shoots obtained from the different treatments, which, when transferred, formed new leaves and well-defined roots and lengthened their stems.

Studies conducted by García-Osuna et al. (2015) confirm the superiority of the explant cotyledonary node in the in vitro production of $P$. ixocarpa shoots. The number of shoots reported by these authors was up to $9.05 \pm 0.57$, at concentrations of $13.2 \mu \mathrm{M}$ of BAP and $2.85 \mu \mathrm{M}$ of NAA. This group worked with a tetraploid variety and, generally, this type of improved population has better characteristics regarding life cycle, fruit weight, number of fruits (Robledo-Torres et al. 2011) and possibly also has better characteristics regarding in vitro morphogenesis.

Closely linked to the potential for regeneration is the organ used and the stage of its development, because, as the specialization of cells progresses during the development of the organ, or plant, gene deprogramming (differentiation) becomes more difficult (Fuzitani \& Nomura 2004). Cotyledonary nodes are meristematic zones with an intense cell division and growth, which is why it is congruent that the highest percentage for the formation of shoots and the highest number of shoots found in the two analyzed varieties of $P$. ixocarpa came from this explant.

It is believed that the exogenous addition of auxins and cytokinins generates a change in the endogenous hormonal balance in the tissues of explants, and the induction, or inhibition, of morphogenic processes in vitro is dependent on the interaction between endogenous and exogenous growth regulatory substances (Monfort et al. 2012). This contributes to clarifying the different responses obtained between the results reported in this study and those present in the literature, in which different concentrations of regulators were used in explants of different varieties, which certainly have different endogenous levels.

The differences obtained for the number of shoots between the purple and the green varieties, with better results for the green one, highlight that the morphogenic capacity is linked to the genotype, as demonstrated by Andrade-Rodríguez et al. (2005) for the same species in vitro.

According to the analysis of variance, the BAP cytokinin influenced alone $(p \leq 0.05)$ the number of shoots per explant in the indirect organogenesis of the Physalis ixocarpa green variety. The shoots showed pale colors and friable texture, small, etiolated leaves and absence of roots.

A mean of 0.58 was observed in the treatment with $2.5 \mu \mathrm{M}$ of BAP, which is higher than the mean of 0.04 generated at the highest BAP concentration used (Figure 5). The data obtained for this variable was not described by any mathematical model as a function of the BAP concentrations used.

The purple variety did not show morphogenic response for the formation of shoots by the indirect pathway under the conditions tested in this study. Thus, considering the low regeneration rates obtained by the green variety and the absence of response in the purple variety, the results indicate that, with the regulators used in this study, this regeneration

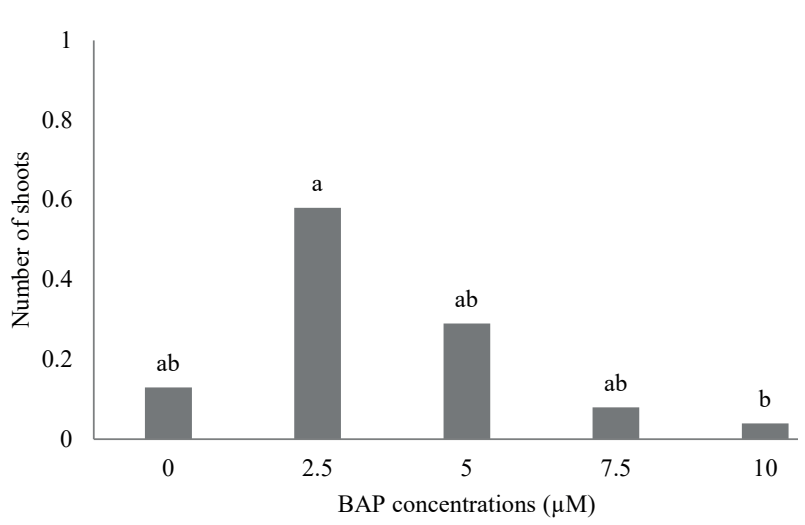

Figure 5. Number of shoots per explant of the Physalis ixocarpa green variety by indirect organogenesis under different benzylaminopurine (BAP) concentrations. Distinct letters indicate difference between the means, according to the Tukey test $(\mathrm{p} \leq 0.05)$. 
pathway is not recommended for these varieties. These results are confirmed by the absence of reports in the literature on morphogenesis from this regeneration pathway for other varieties of $P$. ixocarpa. Possibly other experiments were not successful in obtaining shoots from this pathway, and that is why it is not used in the propagation of this species.

For the percentage of explants with calluses, the analysis of variance indicated a significant double interaction $(\mathrm{p} \leq 0.05)$ between the BAP and NAA concentrations, and a significant single effect for the types of explant of the P. ixocarpa green variety.

The combination between $5 \mu \mathrm{M}$ of BAP and $2.5 \mu \mathrm{M}$ of NAA promoted $80 \%$ of callus formation in explants of the $P$. ixocarpa green variety (Table 3 ). In addition, it was observed that, in the presence of auxin, there was an increase in all rates corresponding to the BAP concentrations, what demonstrates the importance of this class of regulators in callus induction. Regarding the type of explant, the highest rate recorded was $52.5 \%$ for the hypocotyl (Figure 6).

According to the analysis of variance, there was a triple interaction $(p \leq 0.05)$ among the factors type of explant, BAP and NAA concentrations for the variable percentage of explants with callus, in the $P$. ixocarpa purple variety.

A value of $100 \%$ was obtained for callogenesis in all explants, under some combination of cytokinin and auxin (Table 4), what demonstrates the action of plant regulators in the callus production. In the media supplemented with BAP concentrations of 5 and $7.5 \mu \mathrm{M}$, the means obtained for percentage of explants with callus in the presence of $2.5 \mu \mathrm{M}$ of NAA were significantly higher than those obtained in auxin-free medium, regardless of the type of

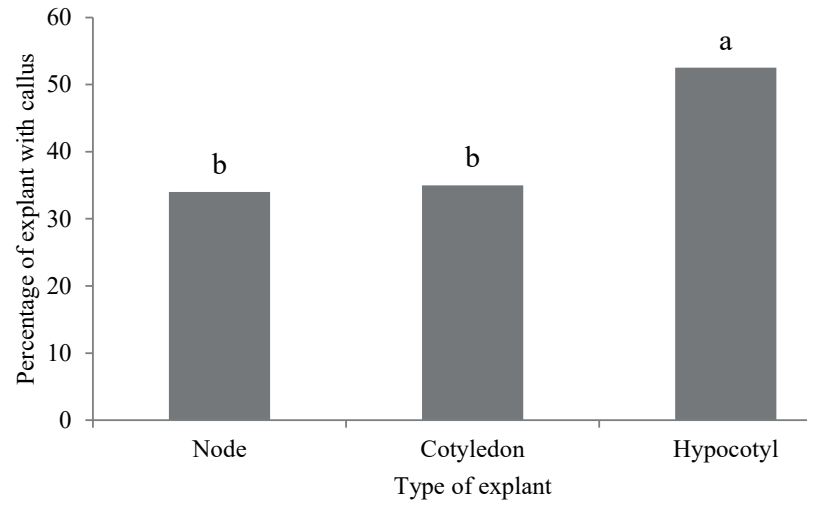

Figure 6. Percentage of explants with callus of the Physalis ixocarpa green variety, in different explants. Distinct letters indicate difference between the means, according to the Tukey test $(\mathrm{p} \leq 0.05)$.

explant (Table 4). These results differ from those reported by Manzo-González (1998), who found differences among the petiole, leaf and stem explants in the callus formation of the P. ixocarpa varieties 'rendidora', 'tamazula' and 'salamanca', using the regulator 2,4-D.

The results obtained for the two studied varieties showed a wide diversity regarding the consistency, friability and color of the calluses, and no relationship was found as a function of the type of explant, plant regulator or variety employed. The callus color was heterogeneous, and it was possible to identify areas of translucent, white, yellowishbrown, dark brown, and light and dark green colors, in combination with friable and hard consistencies (Figure 7). Color is an indicative of callus potential. Translucent-white or yellowish parts are generally considered friable and with embryogenic potential, while greenish parts can be attributed to the exposure of calluses to constant light, what results in the

Table 4. Percentage of callogenesis in explants of the Physalis ixocarpa purple variety under different benzylaminopurine (BAP) and naphthaleneacetic acid (NAA) concentrations.

\begin{tabular}{clccccc}
\hline \multirow{2}{*}{ NAA } & \multicolumn{1}{c}{ Explant } & \multicolumn{5}{c}{$\mathrm{BAP}(\mu \mathrm{M})$} \\
\cline { 3 - 6 } & & 0.0 & 2.5 & 5.0 & 7.5 & 10.0 \\
\hline \multirow{2}{*}{0.0} & Cotyledonary node & $0 \mathrm{Aa}$ & $20 \mathrm{Aa}$ & $5 \mathrm{Aa}$ & $10 \mathrm{Ba}$ & $30 \mathrm{Ba}$ \\
& Cotyledon & $0 \mathrm{Aa}$ & $15 \mathrm{Aa}$ & $0 \mathrm{Aa}$ & $0 \mathrm{Ba}$ & $10 \mathrm{Ba}$ \\
& Hypocotyl & $20 \mathrm{Abc}$ & $15 \mathrm{Ac}$ & $0 \mathrm{Ac}$ & $60 \mathrm{Aab}$ & $90 \mathrm{Aa}$ \\
\hline \multirow{2}{*}{2.5} & Cotyledonary node & $5 \mathrm{Ac}$ & $55 \mathrm{Abc}$ & $60 \mathrm{Bab}^{*}$ & $100 \mathrm{Aa}^{*}$ & $55 \mathrm{Bbc}$ \\
& Cotyledon & $15 \mathrm{Ac}$ & $45 \mathrm{Abc}$ & $95 \mathrm{ABa}^{*}$ & $90 \mathrm{Aab}^{*}$ & $100 \mathrm{Aa}^{*}$ \\
& Hypocotyl & $40 \mathrm{Ab}$ & $35 \mathrm{Ab}$ & $100 \mathrm{Aa}^{*}$ & $100 \mathrm{Aa}^{*}$ & $80 \mathrm{ABab}^{2}$ \\
\hline
\end{tabular}

* Significant for NAA. Distinct letters indicate different means according to the Tukey test $(\mathrm{p} \leq 0.05)$. Uppercase letters compare explants and lowercase letters compare BAP concentrations. 
A
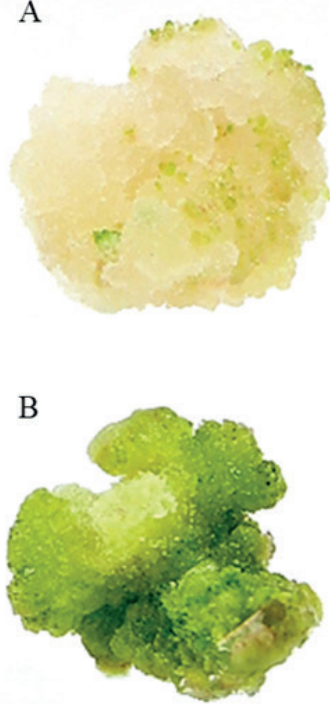

C

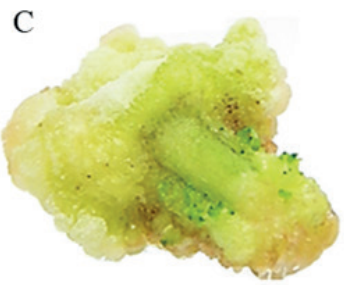

D
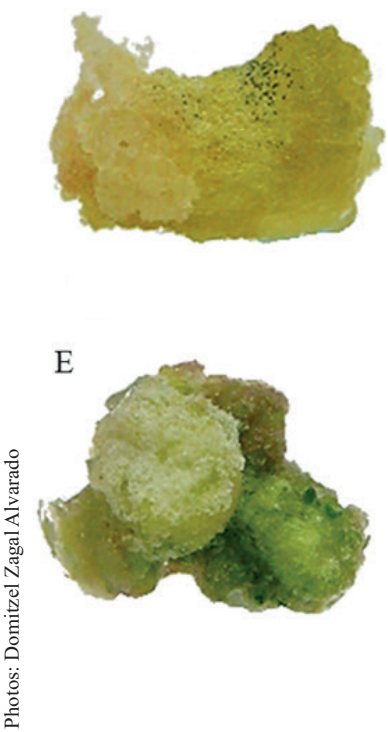

F

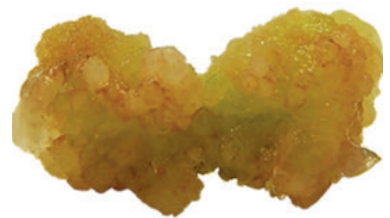

G

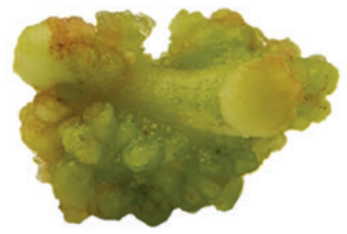

$\mathrm{H}$

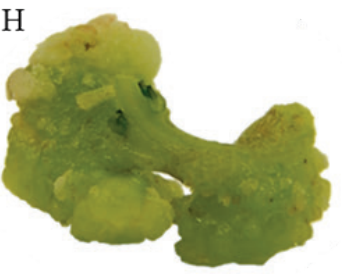

I

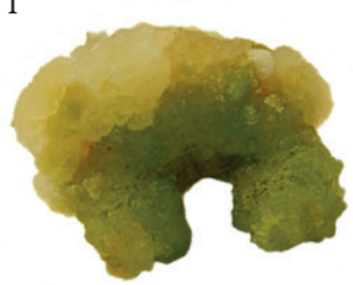

J

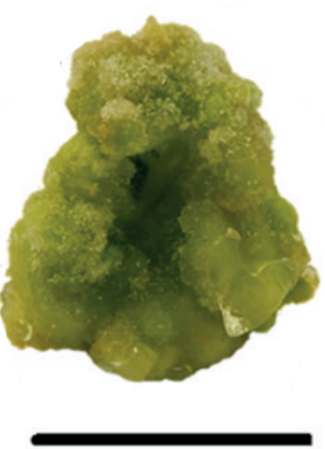

Figure 7. In vitro morphogenic diversity of calluses of Physalis ixocarpa cultured in vitro for 30 days. A-E) green variety; F-J) purple variety. Bar: $1 \mathrm{~cm}$.

synthesis of chlorophyll pigments in cells (Corredoira et al. 2002), and are commonly related to organogenic potential.

As for consistency, Nogueira et al. (2007) consider that friable calluses have the potential to originate somatic embryos; however, although white and green translucent friable calluses were obtained in the present study, there was no pattern as a function of plant regulators or explants employed. Therefore, further studies should be conducted to evaluate the regeneration potential of the various calluses obtained in both varieties.

\section{CONCLUSIONS}

1. The in vitro morphogenetic expression of Physalis ixocarpa is influenced by the type of explant and by the plant regulators benzylaminopurine and naphthaleneacetic acid;

2. The cotyledonary node explant is efficient for the production of shoots via direct organogenesis in the two varieties studied.

\section{REFERENCES}

ANDRADE-RODRÍGUEZ, M.; LÓPEZ-PERALTA, M. C.; GONZÁLEZ-HERNÁNDEZ, V. A.; GARCÍAVELÁZQUEZ, A.; PEÑA-LOMELÍ, A. Efecto del genotipo en la micropropagación de tomate de cáscara. Revista Chapingo Serie Horticultura, v. 11, n. 1, p. 3137, 2005.

BAPAT, V. A.; SCHIEDER, O. Protoplast culture of several members of the genus Physalis. Plant Cell Reports, v. 1, n. 1, p. 69-70, 1981.

BAPAT, V. A.; WENZEL, G. In vitro haploid plantlet induction in Physalis ixocarpa Brot. through microspore embryogenesis. Plant Cell Reports, v. 1, n. 1, p. 154-156, 1982.

BARROSO, N. D.; SOUZA, M. O.; RODRIGUES, L. C.; PELACANI, C. R. Maturation stages of fruits and physiological seed quality of Physalis ixocarpa Brot. Ex Hormen. Revista Brasileira de Fruticultura, v. 39, n. 3, p. 1-9, 2017.

CONTRERAS, I.; PUENTES, A. J. Micropropagación del tomatillo (Physalis ixocarpa L.). Revista de la Facultad de Farmacia, v. 45, n. 1, p. 61-64, 2003.

CORREDOIRA, E.; VIEITEZ, M. A.; BALLESTER, A. Somatic embryogenesis in elm. Annals of Botany, v. 89, n. 5, p. 637-644, 2002.

ESCOBAR-GUZMÁN, R. E.; HERNÁNDEZ-GODÍNEZ, F.; MARTÍNEZ de La VEGA, O.; OCHOA-ALEJO, N. In vitro embryo formation and plant regeneration from anther 
culture of different cultivars of Mexican husk tomato (Physalis ixocarpa Brot.). Plant Cell Tissue, Organ and Culture, v. 96, n. 2, p. 181-189, 2009.

FERREIRA, D. F. Sisvar: a computer analysis system to fixed effects split plot type designs. Revista Brasileira de Biometria, v. 37, n. 4, p. 529-535, 2019.

FUZITANI, E. J.; NOMURA, E. S. Production of in vitro plants. Revista Brasileira de Horticultura Ornamental, v. 10, n. 1/2, p. 15-19, 2004.

GARCÍA-OSUNA, H. T.; ESCOBEDO BOCARDO, L.; ROBLEDO-TORRES, V.; BENAVIDES MENDOZA, A.; RAMÍREZ GODINA, F. Germinación y micropropagación de tomate de cáscara (Physalis ixocarpa) tetraploide. Revista Mexicana de Ciências Agrícolas, v. 6, special issue, p. 2301-2311, 2015.

GOELZER, A.; DÉO, T. G.; LOPES, G. B.; DAMIANI, C. R. Reguladores de crescimento na multiplicação in vitro de Campomanesia adamantium (Cambess.) O. Berg (Myrtaceae). Brazilian Applied Science Review, v. 3, n. 2, p. 1280-1291, 2019.

HERNÁNDEZ, J. F.; VARGAS-PONCE, O.; GRIMALDO JUÁREZ，O.; MAGAÑA-LIRA，N.; COCHEO VERLADE, F.; PEÑA LOMELI, A.; SANCHEZ MARTÍNEZ, J. Perfil del diagnóstico de la red de tomate de cáscara. Guadalajara: Prometeo, 2012.

KERBAUY, G. B. Fisiologia vegetal. Rio de Janeiro: Guanabara Koogan, 2019.

LEVITUS, G.; ECHENIQUE, V.; RUBINSTEIN, C.; HOPP, E.; MROGINSKI, L. Biotecnología y mejoramiento vegetal II. 2. ed. Buenos Aires: INTA, 2010.

MANZO-GONZÁLEZ, A.; LEDESMA-HERNANDEZ, A.; VILLATORO-LÓPEZ, J. C.; ALVAREZ-ESCAREÑO, I.; RODRIGUEZ-DE LA O, J. L.; PEÑA-LOMELÍ, A. Regeneración in vitro de tomate de cáscara (Physalis ixocarpa Brot.). Revista Chapingo Serie Horticultura, v. 4, n. 1 p. 45-49, 1998.

MASCARENHAS, L. M. S.; SANTANA, J. R. F.; LIMABRITO, A. Micropropagation of Physalis peruviana L. Pesquisa Agropecuária Tropical, v. 49, e55603, 2019.
MONFORT, L. E. F.; PINTO J. E. B. P.; BERTOLUCCI, S. K. V.; ROSSI, Z. T. T.; SANTOS, F. M. Efeito do BAP no cultivo in vitro de Ocimum selloi Benth. Revista Brasileira de Plantas Medicinais, v. 14, n. 3, p. 458-63, 2012.

MORAIS, T. P.;ASMAR, S. A.; LUZ, J. M. Q. Reguladores de crescimento vegetal no cultivo in vitro de Mentha $\mathrm{x}$ Piperita L. Revista Brasileira de Plantas Medicinais, v. 16, n. 2, p. 350-355, 2014.

MURASHIGE, T.; SKOOG, F. A revised medium for rapid growth and bioassays with tobacco tissue culture. Physiologia Plantarum, v. 15, n. 4, p. 473-497, 1962.

NOGUEIRA, C. R.; PAIVA, R.; PORTO, J. M. P.; NICIOLI, P. M.; STEIN, V. C.; DEUNER, S.; ALVES, E. Análise ultra-estrutural de calos embriogênicos de murici-pequeno (Byrsonima intermedia A. Juss.). Revista Brasileira de Biociências, v. 5, n. 2, p. 48-50, 2007.

NUNES, A. L.; SOSSMEIER, S.; GOTZ, A.; BISPO, N. Germination eco-physiology and emergence of Physalis peruviana seedlings. Journal of Agricultural Science and Technology, v. 8, n. 1, p. 352-359, 2018.

PASQUAL, M.; SANTOS, C. F.; FIGUEIREDO, M. A. de C.; JUNQUEIRA, P. K.; REZENDE, C. J. de. Micropropagação de abacaxizeiro ornamental. Horticultura Brasileira, v. 26, n. 1, p. 45-48, 2008.

PERES, L. E. P. Bases fisiológicas e genéticas da regeneração de plantas in vitro. Biotecnologia, Ciência e Desenvolvimento, v. 25, n. 1, p. 44-48, 2002.

RAMOS-LÓPEZ, B. I.; ORTIZ-HERNANDEZ, Y. D.; MORALES, I. Yield analysis of Physalis ixocarpa Brot. Ex Hornem varieties under greenhouse and field conditions. Ciência Rural, v. 48, n. 11, p. 1-7, 2018.

ROBLEDO-TORRES, T. V.; RAMIREZ GODINA, F.; FOROUGHBAKHCH, R.; BENAVIDES-MENDOZA, A.; HERNÁNDEZ-GUZMÁN, G.; REYES-VALDES, M. H. Development of tomatillo (Physalis ixocarpa Brot.) auto tetraploids and their chromosome and phenotypic characterization. Breeding Science, v. 61, n. 3, p. 288293, 2011.

RUFATO, A. R. Cultura da physalis. Florianópolis: CNPUV, 2013. 